\title{
Different Tillage Practices and Seed Rates Affected Phenology and Various Growth Stages of Wheat
}

\author{
${ }^{1}$ Department of Agronomy, The University of Agriculture Peshawar, Pakistan \\ ${ }^{2}$ Department of Agricultural Chemistry The University of Agriculture Peshawar, Pakistan \\ ${ }^{3}$ Department of Soil \& Environmental sciences The University of Agriculture Peshawar, Pakistan
}

Sajjad Ahmad ${ }^{1 *}$, Zaid Khan ${ }^{1}$, Hafeez Ur Rahim ${ }^{1}$, Muhammad Ayoub Khan ${ }^{1}$, Usman² and Muhammad Haris ${ }^{3}$

Submission: February 14, 2018; Published: March 29, 2018

"Corresponding author: Sajjad Ahmad, Department of Agronomy, Faculty of Crop Production Sciences, The University of Agriculture Peshawar, Pakistan, Email: sajjad@aup.edu.pk

\begin{abstract}
To evaluate response of phenology and different growth stages to different tillage practices (i.e. 3 Times Chisel Plough +2 Times Rotavator (40 cms), 3 Times Mould Board Plough +2 Times Rotavator $(30 \mathrm{cms}), 2$ Times Disc harrow +2 Times Rotavator $(20 \mathrm{cms}), 1$ Time Cultivator + 1 Time Rotavator (10cms) and seed rates (i.e. 70, 85,100,115,130,145,160,175 $\mathrm{kg} \mathrm{ha}^{-1}$ ). The research experiment was laid out in randomized complete block Design with split plot arrangement with three replications at Agronomy Research Farm, The University of Agriculture Peshawar during winter 2014-2015. Significant effect of different tillage practices on harvest index (\%), straw yield were observed. Highest harvest index (\%) (33.8\%) was recorded from treatment of (2 Time Disc Harrow +2 Time Cultivator $20 \mathrm{~cm})$. Highest straw yield $\left(6735 \mathrm{~kg} \mathrm{ha}^{-1}\right)$ was observed from (3 Mould Board Plough +2 Times Rotavator $30 \mathrm{~cm}$ ). Seed rates showed significant effect on spike length, spikelet spike-1, spike $\mathrm{m}^{-2}$, harvest index (\%), and straw yield. Maximum spike length $(13.96 \mathrm{~cm})$, spikelet's spike ${ }^{-1}(18)$ were recorded with application of seed rate of $70 \mathrm{~kg}$ ha ${ }^{-1}$ while higher spike $\mathrm{m}^{-2}$ (273), straw yield (7013kg ha-1) were observed with application of seed rate $175 \mathrm{~kg}$ ha-1. Maximum harvest index (\%) (35.1\%) was observed with seed rate of $115 \mathrm{~kg} \mathrm{ha}^{-1}$. It is concluded that tillage practices 2 Times Disc harrow +2 Times Rotavator $(20 \mathrm{cms})$ and seed rate of $115 \mathrm{~kg} \mathrm{ha}^{-1}$ produced maximum yield of wheat.
\end{abstract}

Keywords: Tillage; Seed rate; Wheat; Growth stages

\section{Introduction}

Wheat (Triticum aestivum L.) belongs to family Poaceae and is known as king of the cereal. In Pakistan wheat has been the major staple food. Wheat is adapted by wide range of climatic and soil condition [1]. Wheat can be use directly or indirectly by human as diet and as feed by animals. It can be used by one -third population as feed around the globe. The low wheat yield in Pakistan might be due to improper use of tillage practices and seed rates.

Tillage is actually known as the mechanical disturbance of the soil through which the hard surface is broken down to produce a crop [2]. Tillage practices have significant effect on grain yield and kernel length of wheat [3]. Extreme tillage operation along traditional cultivation techniques enhances bulk density of soil. Fabrizzi et al. [4] observe loss of organic nutrients due excessive tillage practices [5]. Maximum tillage operation declines macro porosity and macro aggregates Chan et al. [6] and increases unavailability of nutrient's and moisture to the crop [7]. Tillage operations considerably enhanced soil water status, improved the capacity of soil moisture deposited throughout the summer and wheat growing season associated with conventional tillage [8]. Shah [9] observed that all growth and yield parameters were significantly affected by the sowing methods and seed rates. Huang et al. [10] carried out research to relate the effect of different tillage and irrigation treatments on yield of wheat grown under cotton-wheat cropping system. The results revealed that wheat yield was significantly affected in all treatments. However, effect of tillage on grain yield was non-significant at more number of tillage operations.

Maximum yield can be attained by regulating plant populations established on greater seed rates [11]. It is eminent that increase of seeding rate at early and optimal sowing time is unfavorable but the negative effect of late sowing could be compensated by increase of seed quantity [12]. Hiltbrunner et al. [13] advocated that rationale increase of the seeding density with that of sowing time is an effective to increase the grain yield. Livores et al. [14] used six seeding rates i.e. 150, 175, 250, 
300,400 and 500 seeds $\mathrm{m}^{-2}$ with four adapted wheat varieties including hybrid wheat. Seeding rate affected grain yield and yield components in three of the four environments, but its effect varied with the environment. Manipulation of seed rate was a more reliable factor than cultivar selection for enhancement of weed suppression Kukal \& Aggarwal [15]. Wheat seed size, seeding rate and variety height had no effect on jointed goatgrass plant density. They observed that wheat reduced mature jointed goat grass biomass $46 \%$ and $16 \%$ compared with short wheat in years 1 and 2 of the experiment, respectively. Spikelet biomass was also reduced approximately 70 and $30 \%$ in same respective years [16].

\section{Material and Methods}

\section{Experimental site}

The experiment was conducted at Agronomy Research Farm, The University of Agriculture Peshawar Pakistan, during winter 2014-2015.

\section{Experimental design}

The experiment was conducted at randomized randomize complete block design with split plot arrangement having three replication with sub plot size $\left(9 \mathrm{~m}^{2}\right)$.

\section{Variety}

Wheat variety Atta-Habib was used.

\section{Result and Discussion}

\section{Spike length (cm)}

Table 1: Spike length, Spikelet spike ${ }^{-1}$, Spike $\mathrm{m} 2$ as affected by tillage practices and seed rates.

\begin{tabular}{|c|c|c|c|}
\hline Tillage Operations & Spike Length (Cm) & Spikelet Spike-1 $^{-1}$ & Spike $\mathbf{m}^{-2}$ \\
\hline 3 Chisel Plough+2 Rotavator $(40 \mathrm{~cm})$ & 12.53 & 17 & 231 \\
\hline 3 MB Plough +2 Rotavator $(30 \mathrm{~cm})$ & 13.05 & 17 & 229 \\
\hline 2 Disc harrow +2 Rotavator $(20 \mathrm{~cm})$ & 13.39 & 17 & 245 \\
\hline 1Cultivator+1 Rotavator $(10 \mathrm{~cm})$ & 13.78 & 18 & 252 \\
\hline $\operatorname{LSD}(0.05)$ & NS & NS & NS \\
\hline \multicolumn{4}{|c|}{ Seed Rates (Kg ha $\left.{ }^{-1}\right)$} \\
\hline 70 & $13.96 \mathrm{a}$ & $18 \mathrm{ab}$ & $182 \mathrm{~d}$ \\
\hline 85 & $13.55 \mathrm{ab}$ & $18 \mathrm{ab}$ & $209 c$ \\
\hline 100 & $13.15 \mathrm{bcd}$ & $17 \mathrm{bc}$ & $224 b c$ \\
\hline 115 & $13.40 \mathrm{abc}$ & $18 \mathrm{ab}$ & $235 b$ \\
\hline 130 & $13.29 \mathrm{abc}$ & $18 \mathrm{a}$ & $259 a$ \\
\hline 145 & $12.88 \mathrm{bcd}$ & $17 \mathrm{abc}$ & $262 \mathrm{a}$ \\
\hline 160 & $12.81 \mathrm{~cd}$ & $17 \mathrm{bc}$ & $269 a$ \\
\hline 175 & $12.47 \mathrm{~d}$ & $16 c$ & $273 a$ \\
\hline $\operatorname{LSD}(0.05)$ & 0.72 & 1.12 & 23.61 \\
\hline \multicolumn{4}{|c|}{ NS $=$ Non significant } \\
\hline \multicolumn{4}{|c|}{ Means of the same category followed by different letters are not significantly different at $5 \%$ level of probability } \\
\hline
\end{tabular}

\section{Treatments}

The treatment consist of two factors (1) Tillage practices (2) Seed rates. Tillage practices was allotted to main plot while seed was kept in sub plots. Tillage practices were consist of 3 Chisel Plough +2 Times Rotavator $(40 \mathrm{~cm}), 3$ Times Mould board Plough +2 Times Rotavator $(30 \mathrm{~cm}), 2$ Times Disc harrow +2 Times Rotavator $(20 \mathrm{~cm}), 1$ Time Cultivator +1 Time Rotavator $(10 \mathrm{~cm})$ while the seed rate were consist of $70 \mathrm{kgha}^{-1}, 85 \mathrm{kgha}$ 1, $100 \mathrm{kgha}^{-1}, 115 \mathrm{kgha}^{-1}, 130 \mathrm{kgha}^{-1}, 145 \mathrm{kgha}^{-1}$ and $160 \mathrm{kgha}^{-1}$ respectively.

\section{Agronomic practices}

All agronomic practices were applied uniformly and at appropriate time. Irrigation was applied according to the requirement of the crop.

\section{Data recorded}

Data were recorded on spike length, number of spikelet spike ${ }^{-1}$, spikes $\mathrm{m}^{-2}$, lodging (\%), harvest index (\%) and straw yield $\left(\mathrm{kg} \mathrm{ha}^{-1}\right)$.

\section{Statistical analysis}

The collected were evaluated statistically according to the procedure related to Randomized complete block design with split plot arrangement. Significant F-Test, (LSD) test were used for mean contrasts to identify the significance among the treatment means. 
Spike length of wheat as affected by tillage practices and seed rate on spike length is presented in Table 1. Statistical analysis of the data showed that spike length was not significantly $(p \geq 0.05)$ affected by different tillage practices. Effect of seed rates was significant $(p \leq 0.05)$ on spike length of wheat crop. All possible interactions of tillage practices and seed rates were non-significant $(\mathrm{p} \geq 0.05)$. Highest spike length $(13.78 \mathrm{~cm})$ was produced by tillage practices $(1$ Time Cultivator +1 Time Rotavator $10 \mathrm{~cm})$ followed by $(13.19 \mathrm{~cm})$ and $(13.05 \mathrm{~cm})$ from tillage practices i.e. (2 Times Disc harrow +2 Times Rotavator $20 \mathrm{~cm}),(3$ Times Mould board Plough +2 Times Rotavator $30 \mathrm{~cm})$ respectively. Minimum spike length $(12.53 \mathrm{~cm})$ was recorded from treatment of tillage practices with (3 Times Chisel Plough + 2 Times Rotavator $40 \mathrm{~cm})$. Highest spike length $(13.96 \mathrm{~cm})$, was recorded with application of seed rate $\left(70 \mathrm{~kg} \mathrm{ha}^{-1}\right)$. The treatment of seed rates $85,115,130,100,145,160 \mathrm{~kg} \mathrm{ha}^{-1}$ ranked $2^{\text {nd }}, 3^{\text {rd }}$ and $4^{\text {th }}, 5^{\text {th }}, 6^{\text {th }}$ spike length of $(13.55 \mathrm{~cm}),(13.40 \mathrm{~cm}),(13.29 \mathrm{~cm})$, $(13.15 \mathrm{~cm}),(12.88 \mathrm{~cm})$ and $(12.81 \mathrm{~cm})$ respectively. Minimum spike length $(12.47 \mathrm{~cm})$ was recorded from seed rate of $175 \mathrm{~kg}$ h 1. By application of lower seed rate there will be less intra specific competition for light, water, nutrients, space etc. hence resulting highest spike length for lower seed rates. At higher seed rates there will be more competition for light, moisture, nutrients uptake etc. Hence produce short spike length. Kabir et al. [17] reported the same result that seed rate have significant effect on spike length $(\mathrm{cm})$. The results are in line with Waraich et al. [18] and Shahzad et al. [19].

\section{Spikelet spike ${ }^{-1}$}

Spikelet spike ${ }^{-1}$ of wheat as affected by tillage practices and seed rates is presented in Table 1. Perusal of data showed that spikelet spike ${ }^{-1}$ was not significantly $(\mathrm{p} \geq 0.05)$ affected by different tillage practices. Effect of seed rates was significant $(p \leq 0.05)$ on spikelet spike ${ }^{-1}$ of wheat crop. All possible interactions of tillage and seed rates were non-significant $(p \geq 0.05)$. Greater spikelet spike $^{-1}(18)$ was recorded by tillage practices (1 Time Cultivator + One Time Rotavator $10 \mathrm{~cm}$ ). Minimum spikelet spike ${ }^{-1}$ (17) was

\section{Lodging (\%)}

Table 2: Lodging (\%), Harvest index (\%), Straw yield as affected by tillage practices and seed rates.

\begin{tabular}{|c|c|c|c|}
\hline Tillage Operations & Lodging (\%) & Harvest index (\%) & Straw yield (kg ha ${ }^{-1}$ ) \\
\hline 3 Chisel Plough +2 Rotavator $(40 \mathrm{~cm})$ & 9.83 & $33.7 \mathrm{~b}$ & $6717 \mathrm{bc}$ \\
\hline $3 \mathrm{MB}$ Plough +2 Rotavator $(30 \mathrm{~cm})$ & 13.04 & $33.6 \mathrm{~b}$ & $6735 a$ \\
\hline 2 Disc harrow +2 Rotavator $(20 \mathrm{~cm})$ & 7.96 & $33.8 \mathrm{a}$ & $6707 c$ \\
\hline 1Cultivator+ 1 Rotavator $(10 \mathrm{~cm})$ & 8.67 & $33.7 \mathrm{~b}$ & $6720 \mathrm{~b}$ \\
\hline $\operatorname{LSD}(0.05)$ & NS & 0.08 & 11 \\
\hline \multicolumn{4}{|l|}{ Seed Rates (Kg ha 1) } \\
\hline 70 & 7.58 & $34.0 \mathrm{~b}$ & $6515 f$ \\
\hline 85 & 10 & $34.0 \mathrm{~b}$ & $6526 f$ \\
\hline 100 & 7.92 & $34.1 \mathrm{~b}$ & $6564 \mathrm{e}$ \\
\hline 115 & 10.17 & $35.1 \mathrm{a}$ & $6613 d$ \\
\hline 130 & 10.17 & $34.9 \mathrm{a}$ & $6644 c$ \\
\hline
\end{tabular}


Agricultural Research \& Technology: Open Access Journal

\begin{tabular}{|c|c|c|c|}
\hline 145 & 10.17 & $32.7 \mathrm{c}$ & $6896 \mathrm{~b}$ \\
\hline 160 & 14 & $32.3 \mathrm{~d}$ & $6989 \mathrm{a}$ \\
\hline 175 & 9 & $32.2 \mathrm{~d}$ & $7013 \mathrm{a}$ \\
\hline LSD(0.05) NS & 0.23 & 26 \\
\hline \multicolumn{2}{|c|}{ NS = Non significant } \\
\hline \multicolumn{2}{|c|}{ Means of the same category followed by different letters are not significantly different at 5\% level of probability }
\end{tabular}

Effect of tillage practices and seed rates on lodging (\%) of wheat is presented in Table 2. Perusal of the data indicated that lodging $(\%)$ was not significantly $(p \geq 0.05)$ affected by different tillage practices. Effect of seed rates was also not significant $(\mathrm{p} \geq 0.05)$ on lodging $(\%)$ of wheat crop. All possible interactions of tillage and seed rates were non-significant ( $\mathrm{p} \geq 0.05)$. Maximum lodging (\%) (13.04 \%) for (3 Times Mould board Plough +2 Times Rotavator $30 \mathrm{~cm}$ ), (3 Times Chisel Plough +2 Times Rotavator $40 \mathrm{~cm}$ ) and (1 Time Cultivator + One Time Rotavator $10 \mathrm{~cm}$ ) ranked $2^{\text {nd }}$ and $3^{\text {rd }}$ with lodging (\%) of $(9.83 \%)$ and $(8.67 \%)$ respectively. Minimum lodging (\%) (7.96\%) was recorded for (2 Times Disc harrow +2 Times Rotavator $20 \mathrm{~cm}$ ). Highest lodging (\%) of (14\%) was recorded for seed rate of $160 \mathrm{~kg}$ ha-1. Seed rate of $115,130,140$ resulting lodging (\%) of $(10.17 \%)$. Seed rate of 85,175 and 100 resulting lodging (\%) of $(10 \%),(9 \%)$ and $(7.92 \%)$ respectively. Lowest lodging $(\%)$ of $(7.58 \%)$ was recorded for seed rate of $70 \mathrm{~kg} \mathrm{ha}^{-1}$.

\section{Harvest index (\%)}

Harvest index (\%) of wheat as affected by tillage practices and seed rates is presented in Table 2. Analysis data showed that harvest index (\%) was significantly $(\mathrm{p} \leq 0.05)$ affected by different tillage practices. Effect of seed rates was also significant $(\mathrm{p} \leq 0.05)$ on harvest index (\%) of wheat crop. All possible interactions of tillage and seed rates were non-significant $(\mathrm{p} \geq 0.05)$. Highest harvest index (\%) (38.8\%) was produced by tillage practices (2 Time Disc harrow +2 time rotavator $20 \mathrm{~cm}$ ) followed by $(33.7 \%)$ harvest index (\%) from tillage practices i.e. (1 Time Cultivator + 1 Time Rotavator $10 \mathrm{~cm}$ ), (Three Times Chisel Plough +2 Times Rotavator $40 \mathrm{~cm}$ ) respectively. Minimum grain yield (33.6\%) was recorded from treatment of tillage practices with (3 Times Mould board Plough +2 Times Rotavator $30 \mathrm{~cm}$ ). Harvest index (\%) was significantly affected by different tillage practices might be due use of different tillage treatments under dry conditions reported that the most soil moisture at tillage with chisel obtained. So, any tillage method that can save moisture at critical development stages, especially at the grain filling stage can be effective in the stability of these traits. Enough moisture in the grain filling stage prevents to shortening grain filling during and grain weight increases and hence affect harvest index (\%) of crop. Our result are also in line with [21]. Shams \& Rafiee [22] also reported the same trend. Our results are also in agreement with [23]. Highest harvest index (\%) (35.1\%) was recorded with application of seed rate (115kg ha-1). The treatment of seed rates 130,100 , $85,70,145$ and $160 \mathrm{~kg} \mathrm{ha}^{-1}$ ranked $2^{\text {nd }}, 3^{\text {rd }}, 4^{\text {th }}, 5^{\text {th }}$ and $6^{\text {th }}$ with harvest index (\%) of (34.9\%), (34.1\%), (34\%), (34\%), (32.7\%), and (32.3\%) respectively. Minimum harvest index (\%) (32.2\%) was recorded from seed rate of $175 \mathrm{~kg} \mathrm{ha}^{1}$. Similar results were reported by Naseem et al. [24] and Thakur et al. [25] found that wheat was quite responsive to increased seed rate; the highest seed rate produced greater plant population $\mathrm{m}^{2}$; suggesting $115 \mathrm{~kg} \mathrm{ha}^{-1}$ seed rate for achieving good crop growth and higher grain yields and harvest index (\%).

\section{Straw yield (kg ha-1)}

Straw yield of wheat as affected by tillage practices and seed rates is presented in Table 2. Mean value of the data revealed that straw yield of wheat was significantly $(\mathrm{p} \leq 0.05)$ affected by different tillage practices. Effect of seed rates was also significant $(p \leq 0.05)$ on straw yield of wheat crop. All possible interactions of tillage and seed rates were non-significant $(\mathrm{p} \geq 0.05)$. Maximum straw yield (6735 $\left.\mathrm{kg} \mathrm{ha}^{-1}\right)$ was produced by tillage practices (3 Times Mould board Plough +2 Times Rotavator $30 \mathrm{~cm}$ ) followed by (6720kg ha-1), (10126 $\left.\mathrm{kg} \mathrm{ha}^{-1}\right)$ from tillage practices i.e. (1 Time Cultivator +1 Time Rotavator $10 \mathrm{~cm}$ ), (3 Times Chisel Plough +2 Times Rotavator 40 ) $\mathrm{cm}$ respectively. Minimum straw yield $\left(6707 \mathrm{~kg} \mathrm{ha}^{-1}\right)$ was recorded from treatment of tillage practices with (2 Times Disc harrow +2 Times Rotavator $20 \mathrm{~cm}$ ). Significant effect of different tillage might be due to tillage practices preferred healthier root development and nutrient uptake by the crop and hence positive physiological and metabolic activities and reproductive development of crop were probably influenced by increased tillage practices. Tillage practice influences favourably the soil-water-plant ecosystem, there by affecting crop yields and straw yield as well. Ardell et al. [26], Ranjan et al. [27], Jabro et al. [28] stated that tillage had significant effect on crop yields. Greater straw yield $(7013 \mathrm{~kg}$ ha-1), was recorded with application of seed rate $\left(175 \mathrm{~kg} \mathrm{ha}^{-1}\right)$. The treatment of seed rates $160,145,130,115,100$ and $85 \mathrm{~kg} \mathrm{ha}^{-1}$ ranked $2^{\text {nd }}, 3^{\text {rd }}$ and $4^{\text {th }}, 5^{\text {th }}, 6^{\text {th }}$ with straw yield of $\left(6989 \mathrm{~kg} \mathrm{ha}^{-1}\right)$, (6896kg ha-1), (6644kg ha-1), (6613kg ha-1), (6564kg ha-1), and $\left(6526 \mathrm{~kg} \mathrm{ha}^{-1}\right)$ respectively. Minimum straw yield $\left(6515 \mathrm{~kg}^{-}\right.$ $\left.{ }^{1}\right)$ was recorded from seed rate of $70 \mathrm{~kg} \mathrm{~h}$. These results are in agreement with Marwat et al. [29], Khan et al. [30] stated that the increase in straw yield with higher seed rate might be due to more number of plants per unit area, though with reduced tillers.

\section{Conclusion}

It was concluded that tillage practices i.e two times disc harrow plus two times rotavator with depth of $20 \mathrm{~cm}$ and by using seed rate of $115 \mathrm{~kg} \mathrm{ha}^{-1}$ resulted higher harvest index (\%) and yield under for wheat crop. 


\section{References}

1. Khalil IA, Jan (2002) Cereal crops. In: cropping technology. A text book of agriculture new millennium edition. National book foundation. pp. 169.

2. Muqaddas B, Ranjha AM, Abid M, Iqbal M (2005) Soil physical properties and wheat growth as affected by tillage and farm manure. Pak J Agric Sci 42(3-4): 56-62.

3. Ozpinar S (2006) Effects of tillage on productivity of a winter wheatvetch rotation under dryland Mediterranean conditions. Soil and Tillage Res 89: 258-265.

4. Fabrizzi KP, Garcia FO, Costa JL, Picone LI (2005) Soil water dynamics, physical Properties and corn and wheat responses to minimum and no tillage systems in the southern Pampas of Argentina. Soil Tillage Res 81(1): 57-69.

5. Stewart BA (2003) Fire in the soil. Enable Newsletter of the Association for Better Land The southern Pampas of Argentina. Soil Tillage Res 81: 57-69.

6. Chan KY, Heenan DP (2007) The effects of stubble burning and tillage on soil Carbon sequestration and crop productivity in southeastern Australia. Soil Use Manage 21(4): 427-431.

7. Sue UA, Rahman MU, Odhano EA, Gul S, Tareen AQ (2009) Effects of Sowing Method and Seed Rate on productivity of wheat. J. Sub Trop Agric Res Dev 2: 57-62.

8. Talukdar ASMHM, Sufian A, Dxbury JM, Lauren JG, Meinser CA (2004) Effect of tillage options and seed rate on grain yield of wheat. J Sub trop Agric Res Dev 2: 57-62.

9. Shah WA (2011) Yield and yield components of wheat as affected by different seed rates and nitrogen level. Sarhad J Agric 27(1): 18-25.

10. Huang GB, Qiang C, Fu-xue F, Ai-zhong Y (2012) Effects of Different Tillage Systems on Soil Properties, Root Growth, Grain Yield, and Water Use Efficiency of Winter Wheat. Journal of Integrative Agriculture 11(8): 1286-1296.

11. Baloch MS (2010) Effect of seeding density and planting time on growth and yield attributes of wheat. The Journal of Animal \& Plant Sciences 20(4): 239-240.

12. Pan QY, Sammons DJ, Kratochil RJ (1994) Optimizing seeding rate for late-seed winter wheat in the Middle Atlantic Region. J Prod Agri 7(2): 221-224.

13. Hiltbrunner J, Streit B, Liedgens M (2007) Are seeding densities an opportunity to increase grain yield of winter wheat in a living mulch of white clover? Field Crop Res 102(3): 163-171.

14. Liovers J, Manent J, Viudas J, Pez AL, Scantier P (2004) Seeding rate influence on yield and. Yield components of irrigated winter wheat in Mediterranean climate. J Agron 96(5): 1258-1265.

15. Kukal SS, Aggarwal GC (2003) Puddling depth and intensity effects in rice-wheat system on a sandy loam soil. Development of subsurface compaction. Soil Till Res 72(1): 1-8.

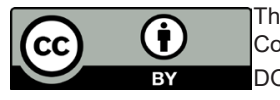

This work is licensed under Creative Commons Attribution 4.0 License DOI: 10.19080/AROAJ.2018.14.555939
16. Joseph PY, Young FL (2004) Winter wheat completion against jointed goatgrass as influenced by wheat plant height, Seeding rate, and seed size. J Bioone 52(6): 996-1001.

17. Kabir, AR Khan, MA Islam, MR Haque (2009). Effect of seed rate and irrigation level on the performance of wheat. J Bangladesh Agril Univ $7(1): 47-52$.

18. Waraich SA, Yasmin S, Ashraf S (1981) Genetic parameters influenced by seeding dates in wheat. Pakistan J Agric Res 3: 273-276.

19. Shahzad MA, Din WU, Sahi ST, Khan MM, Ehsanullah, et al. (2007) Effect of sowing dates and seed treatment on grain yield and quality of wheat. Pakistan J Agri Sci 44(4): 581-583.

20. Longnecker N, Kirby EJM, Robson A (1993) Leaf emergence, tiller growth, and apical development of nitrogen-deficient spring wheat. Crop Sci 33(1): 154-160.

21. Mohammadi KH, Nabi Allahi K, Aghaalikhani M, Khormali F (2009) Study on the effect of different tillage methods on the soil physical properties, yield and yield components of rainfed wheat. Iranian Journal of Plant Production 16(4): 77-91.

22. Shams AHA, Rafiee S (2007) Study on the effect of tillage practices and different seed densities on yield of rainfed wheat. J of Agri Sci and Nat Res 13: 95-102.

23. Asghari MJ (2006) Study on the effects of soil tillage methods and crop residue management on wheat grain yield in dryland. 4 National Congress on Agriculture Machinery Engineering and Mechanization 29-30 August 2006. Tabriz University, Iran, pp. 14-15.

24. Naseem K, Qureshi ARH, Akhtar J, Masood MA (2002) Screening of wheat (Triticum aestivum L.) genotypes against salinity in solution culture. Pakistan J Agric Sci 37: 1-6.

25. Thakur SS, Pandev IS, Singh SJ, Mishr SS (1996) Effect of seed rate and row spacing on late sown wheat in alluvial calcareous soil. J Res Bisra Agric Univ 2: 123-125.

26. Ardell D, Halvorson AL, Black JN, Krupingley SD, Merril BJ, et al. (2000) Spring wheat response to tillage system and nitrogen fertilization within crop tallow system. Agron J 92: 288-294.

27. Ranjan B, Singh RD, Chandra S, Kundu S, Gupta HS (2006) Effect of tillage and irrigation on yield and soil properties under rice, wheat system on a sandy clay loam soil of Uttaranchal. Indian J Agric Sci 76(7): 405409.

28. Jabro JD, Sainju UM, Stevens WB, Lenssen AW, Evans RG (2008) Longterm tillage frequency effects on dry land soil physical and hydraulic properties. International Soil Conservation Organization Conference Proceeding. May 15-23. 2008. Budapest, Hungary, pp. 1-4.

29. Marwat AQ, Khalil SK, Wazir AL, Iqbal M (1989) Effect of land preparation and seeding rates on plant height and straw yield on wheat. Sarhad J Agric 5 (3): 273-278.

30. Khan AI, Bakht J, Shah AW, Khan NM, Ullah I (2002) Effect of seed rate on the yield and yield components of wheat under irrigated conditions of Peshawar. Asian J Plant Sci 1(5): 513-515.

\begin{tabular}{|l|}
\hline \multicolumn{1}{|c|}{ Your next submission with Juniper Publishers } \\
will reach you the below assets \\
- Quality Editorial service \\
- Swift Peer Review \\
- Reprints availability \\
- E-prints Service \\
- Manuscript Podcast for convenient understanding \\
- Global attainment for your research \\
- Manuscript accessibility in different formats \\
( Pdf, E-pub, Full Text, Audio) \\
- Unceasing customer service \\
Track the below URL for one-step submission \\
https://juniperpublishers.com/online-submission.php
\end{tabular}

